\title{
Detection of hepatopancreatic parvovirus (HPV) of penaeid shrimp by in situ hybridization at the electron microscope level
}

\author{
C. R. Pantoja*, D. V. Lightner \\ The University of Arizona, Department of Veterinary Science and Microbiology, 1117 E. Lowell St., Bldg. \#90, Room 114, \\ Tucson, Arizona 85721, USA
}

\begin{abstract}
A post-embedding in situ hybridization procedure was developed to detect hepatopancreatic parvovirus (HPV) of penaeid shrimp at the ultrastructural level. The procedure was optimized using sections of resin-embedded hepatopancreas from HPV-infected juvenile Penaeus monodon and postlarval $P$. chinensis. The hepatopancreata were fixed using various fixatives, dehydrated, and embedded in the hydrophilic resin Unicryl ${ }^{\mathrm{TM}}$. A 592 bp HPV-specific DNA probe, labeled with DIG11-dUTP, was tested both on semi-thin and ultra-thin sections and examined by light and electron microscopy, respectively. Hybridized probe was detected by means of an anti-DIG antibody conjugated to $10 \mathrm{~nm}$ gold particles and subsequent silver enhancement. Hybridization signal intensities were similar with all fixatives tested, but ultrastructure was best preserved with either 2 or $6 \%$ glutaraldehyde. Post-fixation with $1 \%$ osmium tetroxide improved ultrastructure but markedly decreased hybridization signal and induced non-specific deposition of gold and silver. Under optimized conditions, this technique was used to successfully follow the development of HPV from absorption and transport through the cytoplansm to nuclear penetration, replication and release by cytolysis. The probe signal was consistently observed among necrotic cell debris within the lumen of hepatopancreatic tubules, within the microvillous border of tubule epithelial cells, within the cytoplasm, and within diagnostic HPV intranuclear inclusion bodies. The nucleolus and karyoplasm of patently infected cells (i.e., showing HPV intranuclear inclusion bodies) were almost devoid of signal. Electron-lucent structures, known as intranuclear bodies, commonly found within the virogenic stroma, showed only weak labeling. This is the first use of in situ hybridization to detect HPV nucleic acids with the electron microscope. The technique should be useful for studying the pathogenesis of HPV.
\end{abstract}

KEY WORDS: Parvoviridae - HPV - Ultrastructural in situ hybridization · Transmission electron microscopy $\cdot$ Penaeus monodon $\cdot$ Penaeus chinensis

\section{INTRODUCTION}

It has been almost 15 yr since hepatopancreatic parvovirus (HPV) was first reported (Lightner \& Redman 1985) and its relevance as a pathogen of penaeid shrimp still remains poorly understood. The lack of animal models or HPV-susceptible shrimp cell lines has hampered the study of the disease. Most informa-

*E-mail: cpantoja@u.arizona.edu tion on the pathology, mode(s) of transmission, virulence, shrimp species and age susceptibility has been inferred from field observations or studies of shrimp naturally-infected by this virus (Lightner \& Redman 1991, Lightner et al. 1992, 1993, Flegel et al. 1999).

Furthermore, the importance of HPV as a diseasecausing agent in shrimp aquaculture facilities may be underestimated due to the characteristic absence of HPV-specific clinical signs, the frequency with which HPV appears in co-infections with other hepatopancreatic pathogens, and the need for specialized detec- 
tion methods including histology, in situ hybridization or PCR (Lightner et al. 1993, Mari et al. 1995, Pantoja \& Lightner 2000).

HPV infection in cultured shrimp has been linked to chronic mortalities during the early larval and/or postlarval stages (Lightner et al. 1993, Spann et al. 1997), and it may result in stunted growth during the juvenile stages (Flegel et al. 1992, 1999, Limsuwan 1999). The effect of HPV on adult shrimp is unknown but it may compromise their survival if the infection is severe and if the shrimp is in a highly demanding metabolic state (i.e., during gonad maturation) (D.V.L. unpubl).

Currently, HPV is considered as a member of the Parvoviridae (Bonami et al. 1995); however, its position within the family still remains uncertain. Apparently HPV shares more similarities with the autonomous parvoviruses than with the arthropod-infecting parvoviruses (densoviruses) (Bonami et al. 1995, Pantoja 1999).

Although HPV-specific gene probes have been developed (Mari et al. 1995), they have been used mostly for diagnostic purposes and not to study the pathogenesis of the disease. Ultrastructural studies on the replication cycle of HPV are also non-existent. Individual HPV particles are very difficult to visualize (unless they aggregate to form recognizable inclusion bodies or paracrystalline arrays) because their size and shape are very similar to normal cellular components such as ribosomes.

In situ hybridization combined with electron microscopy can help to overcome such problems, and many improvements to the original method (Jacob et al. 1971) have increased its attractiveness. For example, long exposure times, limited resolution and low sensitivity associated with isotopic probes (Binder 1987) have been overcome by the use of highly sensitive non-radioactive probes when combined with improved embedding resins (Binder 1987, Beals 1992, Morey 1995, Le Guellec 1998). Intracellular replication of at least 7 different viruses has now been studied using this approach (Geuskens \& May 1974, Puvion-Dutilleul \& Puvion 1989, 1990, 1991, Escaig-Haye et al. 1992, Multhaupt et al. 1992, Morey et al. 1993).

We report here the adaptation of conventional HPV in situ hybridization techniques - originally developed for light microscopy on paraffin sections - to electron microscopy on Unicryl ${ }^{\mathrm{TM}}$-embedded ultrathin sections. Using this method, it was possible to follow aspects of the infection and development cycle of HPV not previously possible by light and electron microscopy.

\section{MATERIALS AND METHODS}

Shrimp species. HPV-infected juvenile Penaeus monodon (average weight $0.15 \mathrm{~g}$ ) originating from Mada- gascar, were transported live to The University of Arizona and reared in a $2000 \mathrm{l}$ fiberglass tank with 30 ppt artificial seawater (Marinemix, Marine Enterprises International, Inc., Baltimore, MD), at $28 \pm 2{ }^{\circ} \mathrm{C}$. Live HPV-infected $P$. chinensis postlarvae (PL10-15) from the Yellow Sea Fishery Research Institute in China were similarly reared in artificial seawater at 25 ppt and $25 \pm 2{ }^{\circ} \mathrm{C}$. Ammonia and nitrite were maintained at levels below $0.5 \mathrm{mg} \mathrm{l}^{-1}$ by using preactivated biological filters. The taxonomy of the shrimp used is according to Holthuis (1980).

Fixation, embedding, and sectioning. Three different fixatives were tested to determine which best preserved ultrastructure without interfering with in situ hybridization with a DIG-labeled HPV probe (592 bp). The fixatives were (1) $4 \%$ paraformaldehyde/0.25\% glutaraldehyde, (2) $2 \%$ glutaraldehyde, and (3) $6 \%$ glutaraldehyde. All fixatives were prepared with $0.15 \mathrm{M}$ Millonig's phosphate buffer ( $\mathrm{pH}$ 7.0) supplemented with $1 \%$ sodium chloride and $0.5 \%$ sucrose (Lightner 1996). Ice-cold fixative, approximately $1 / 10$ of the total volume of the shrimp, was first injected into the hepatopancreas prior to it being dissected and cut into small pieces $\left(\sim 1 \mathrm{~mm}^{3}\right)$ in ice-cold phosphate buffer. Tissue pieces from each shrimp were transferred to $1 \mathrm{ml}$ of the same fixative and fixed for $6 \mathrm{~h}$ under refrigeration $\left(\sim 4^{\circ} \mathrm{C}\right)$. Hepatopancreas samples from 5 shrimp of each species were fixed in each fixative.

After fixation, tissues were rinsed twice with ice-cold phosphate buffer and divided into 2 portions, one of which was post-fixed with $1 \%$ osmium tetroxide (in phosphate buffer) for $1 \mathrm{~h}$ at room temperature (RT; $25^{\circ} \mathrm{C}$ ) and the other not. From this point all samples were processed in identical fashion. Specimens were dehydrated at RT in a graded series of ethanol (15 min each in $30,50,70,80$, and $95 \%$, and twice in absolute ethanol) and infiltrated at $4^{\circ} \mathrm{C}$ with increasing concentrations of the hydrophilic Unicryl ${ }^{\mathrm{TM}}$ resin (British BioCell International Ltd, Golden Gate, Cardiff, UK) as follows: $24 \mathrm{~h}$ in resin: absolute ethanol (1:2), $24 \mathrm{~h}$ in resin: absolute ethanol (2:1) followed by $24 \mathrm{~h}$ in pure resin. Resin-infiltrated specimens were transferred into Beem capsules containing fresh resin and polymerized at $-10^{\circ} \mathrm{C}$ for approximately $72 \mathrm{~h}$ by exposure to UV light provided by $2 \times 15 \mathrm{~W}$ Phillips UV lamps, $360 \mathrm{~nm}$ wavelength, set at approximately $15 \mathrm{~cm}$ under the Beem capsules.

Semi-thin sections (1 $\mu \mathrm{m}$ thickness) were placed on a drop of double-distilled water on a regular microscope glass slide and heat dried at $60^{\circ} \mathrm{C}$ for 1 to $2 \mathrm{~min}$, stained with $1 \%$ toluidine blue in $1 \%$ sodium borate at $60^{\circ} \mathrm{C}$ for $1 \mathrm{~min}$ and then observed with a light microscope for the presence of diagnostic HPV intranuclear inclusions (Lightner 1996). Consecutive semi-thin sections were placed on drops of HPLC (high performance liquid 
chromatography) quality water on a Superfrost/Plus positively charged microscope slide (Fisher Scientific, Pittsburgh, PA), heat dried and stored at room temperature until needed ( 2 to $3 \mathrm{~d}$ ). Four such slides were prepared from each block. Two to 3 consecutive ultra-thin sections (gold interference color) from the same blocks were placed on each of 5 carbon/Formvar-coated 100mesh nickel grids and stored, unstained, at RT until needed (not more than $1 \mathrm{wk}$ ).

Preparation of probe EC592. A $592 \mathrm{bp}$ fragment from the HPV DNA genome was amplified by PCR using purified Korean HPV as a template and HPVspecific primers (1120F/1120R) as previously described by Pantoja \& Lightner (2000). The amplified product was electrophoresed in a $1 \%$ low melting point agarose gel, the band was excised and the DNA purified using agarase (Roche Molecular Biochemicals, Indianapolis, IN). The purified 592 bp product was randomly labeled with digoxigenin (DIG)-11-dUTP using the Genius I Kit (Roche Molecular Biochemicals) according to the manufacturer's protocol. Labeled DNA (designated EC592 probe) was visualized with alkaline phosphatase-conjugated anti-digoxigenin antibody and the substrate nitroblue tetrazolium (NBT) and 5-bromo-4-chloro-3-indoyl phosphate (BCIP), supplied with the Genius I Kit.

In situ hybridization for light microscopy. Hybridization of the EC592 probe to HPV nucleic acids in resin-embedded hepatopancreas was first assessed by light microscopy. Positive and negative controls for this phase of the study were paraffin sections of HPVinfected Penaeus chinensis and specific pathogen-free (SPF; Lotz et al. 1995) P. vannamei, respectively. Paraffin sections were subjected to in situ hybridization with the probe EC592 according to standard procedures reported elsewhere (Lightner 1996), except that the probe detection step was modified for use with plastic sections as described below.

In situ hybridizations on semi-thin plastic sections were performed in duplicate, with 1 group of slides used as a negative control (i.e., no probe added to the hybridization solution). Sections were re-hydrated at RT by immersion for 5 min in HPLC water followed by 5 min TNE $\left(50 \mathrm{mM}\right.$ Tris- $\mathrm{HCl}_{1} 10 \mathrm{mM} \mathrm{NaCl}, 1 \mathrm{mM}$ EDTA, pH 7.4). The effect of proteolytic digestion was evaluated by subjecting re-hydrated sections to the following treatments: (1) no digestion, (2) 5 min digestion and (3) 15 min digestion with $100 \mathrm{\mu g} \mathrm{ml}^{-1}$ Proteinase K (Sigma Chemical, St. Louis, MO) in $1 \mathrm{TNE}$ at $37^{\circ} \mathrm{C}$.

Proteinase $\mathrm{K}$ was inactivated by a 5 min rinse in icecold $0.4 \%$ formaldehyde and sections were soaked 5 min in $2 \times$ standard saline citrate $(\mathrm{SSC} ; 1 \times=0.15 \mathrm{M}$ $\mathrm{NaCl}, 0.015 \mathrm{M}$ sodium citrate, $\mathrm{pH}$ 7.0). A volume of $0.5 \mathrm{ml}$ of hybridization solution $(50 \%$ formamide, $0.02 \%$ Ficoll $400,0.02 \%$ polyvinylpyrolydone 360,
$0.02 \%$ bovine serum albumin [BSA], $5 \%$ dextran sulfate, $0.5 \mathrm{mg} \mathrm{ml}^{-1}$ denatured salmon sperm DNA, $4 \times$ $\mathrm{SSC}$ ) was poured on to the sections and the slides incubated in a humid chamber at $37^{\circ} \mathrm{C}$ for $30 \mathrm{~min}$. Probe EC592 was denatured at $100^{\circ} \mathrm{C}$ for $10 \mathrm{~min}$, quenched

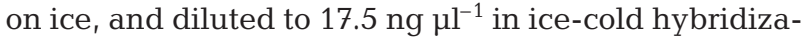
tion solution. Probe $(250 \mu \mathrm{l})$ was placed onto each of the slides, which were incubated overnight at $37^{\circ} \mathrm{C}$ in a humid chamber. Negative control slides were incubated in hybridization solution only.

Post-hybridization washes employed decreasing concentrations of SSC buffer at $37^{\circ} \mathrm{C}(2 \times 5$ min each in $2 \times$ SSC, $1 \times$ SSC, $0.5 \times$ SSC and $0.1 \times$ SSC). Slides were soaked for $5 \mathrm{~min}$ at RT in Buffer I $(0.1 \mathrm{M}$ Tris- $\mathrm{HCl}$, $0.15 \mathrm{M} \mathrm{NaCl}, \mathrm{pH} 7.5$ ) and blocked for $15 \mathrm{~min}$ at $37^{\circ} \mathrm{C}$ with $0.5 \mathrm{ml}$ of $10 \mathrm{mg} \mathrm{ml}^{-1}$ Blocking reagent (Roche Molecular Biochemicals) in Buffer I. Hybridized probe was detected with sheep anti-digoxigenin antibody conjugated to $10 \mathrm{~nm}$ gold particles (British BioCell International Ltd; OD[optical density $]_{520}=3.0$ ) diluted to $3.49 \mathrm{\mu g} \mathrm{ml}^{-1}$ in blocking buffer. Diluted conjugate $(10 \mu l)$ was placed onto the sections, which were covered with a glass cover slip and incubated in a humid chamber at $37^{\circ} \mathrm{C}$ for $30 \mathrm{~min}$. Unreacted gold conjugate was removed by rinsing slides $4 \times 5 \mathrm{~min}$ in Buffer I at RT, followed by 4 separate 5 min rinses in HPLC water. Silver enhancement was performed with a silver enhancing kit (British BioCell International Ltd). Silver enhancing solution $(20 \mu \mathrm{l})$ was placed onto sections, which were covered with a cover slip and incubated at $28^{\circ} \mathrm{C}$ for $1.5 \mathrm{~h}$ in the dark. The reaction was stopped by immersion in HPLC water for $15 \mathrm{~min}$. Slides were heat dried at $60^{\circ} \mathrm{C}$ for 1 to $2 \mathrm{~min}$, stained with $1 \%$ toluidine blue in $1 \%$ sodium borate at $60^{\circ} \mathrm{C}$ for $0.5 \mathrm{~min}$, mounted with Permount (Fisher Scientific) and examined using a bright field light microscope for black silver precipitate indicating probe hybridization.

In situ hybridization for electron microscopy. After having confirmed the ability of probe EC592 to detect HPV in semi-thin plastic sections, ultra-thin sections were hybridized with the same probe. Except for a few modifications, the hybridization protocol for ultra-thin sections was the same as that used for semi-thin sections. All reactions were performed by floating the grids, section side down, on $20 \mu \mathrm{l}$ drops of reagent. All buffers, solutions and incubation temperatures were the same unless stated otherwise. Excess solution on the grids was blotted away between steps and all incubations were done inside a humid chamber.

Briefly, grids were re-hydrated, incubated 5 min in TNE and treated with $100 \mu \mathrm{g} \mathrm{ml}^{-1}$ Proteinase $\mathrm{K}$ for 5 min. Proteinase $\mathrm{K}$ was inactivated as above and grids incubated for $5 \mathrm{~min}$ in $2 \times \mathrm{SSC}$ and for $30 \mathrm{~min}$ in hybridization solution. The grids were incubated overnight (approximately $16 \mathrm{~h}$ ) on drops of denatured 
EC592 probe (17.5 ng $\mu^{-1}$ ) in hybridization solution (test group) or in hybridization solution alone (negative controls). Posthybridization washes were performed on decreasing concentrations of SSC buffer as above after which the grids were soaked for 5 min in Buffer I and for 15 min in blocking buffer.

DIG-labeled probe was detected by floating the grids on $10 \mu \mathrm{l}$ drops of anti-DIG gold conjugate for $30 \mathrm{~min}$. Grids were rinsed $4 \times$ $5 \mathrm{~min}$ in Buffer I followed by $4 \times 5$ min rinses in HPLC water prior to silver enhancement in $20 \mu \mathrm{l}$ drops of silver enhancing solution for $5 \mathrm{~min}$ at $18^{\circ} \mathrm{C}$ in the dark. The reaction was terminated by floating the grids on HPLC water for $15 \mathrm{~min}$ followed by air-drying. Finally, sections were stained with lead citrate and uranyl acetate and viewed using a Phillips CM12 electron microscope operated at $80 \mathrm{kV}$.

\section{RESULTS}

\section{In situ hybridization with light microscopy}

Positive hybridization to the EC592 probe was observed in both HPV-positive paraffin and resin-embedded hepatopancreas of Penaeus monodon and $P$. chinensis. A black precipitate indicating the site of hybridization was observed on the microvillous border of tubule epithelial cells, within the cytoplasm, and within diagnostic intranuclear inclusions at various stages of development (Fig. 1). Hybridization signals observed on plastic semi-thin sections were not as strong as those seen on paraffin sections (not shown).

The intensity of hybridization signal on semi-thin plastic sections was similar irrespective of the fixative employed. The inclusion of a proteolytic digestion step did, however, increase signal intensity similarly with either a 5 or 15 min digestion. However, negative controls indicated that non-specific deposition of silver occurred more frequently on specimens digested for $15 \mathrm{~min}$. Osmication, on the other hand, markedly decreased probe signals (results not shown).

Significant non-specific deposition of silver was detected within the cytoplasm of tubule epithelial cells of the hepatopancreas in paraffin sections in which probe was omitted (not shown). Additional testing indicated that

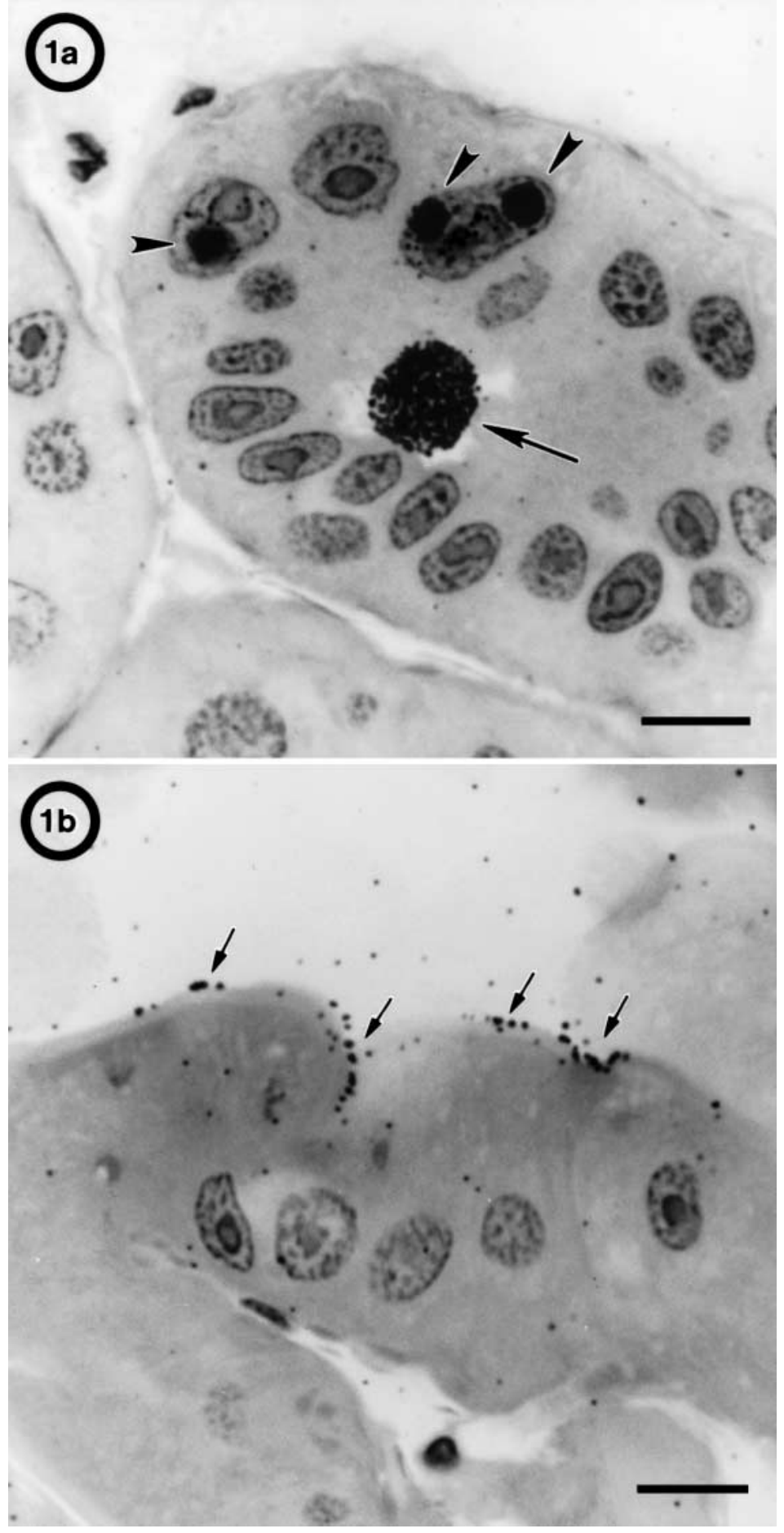

Fig. 1. Light microscopy of semi-thin sections of Unicryl-embedded hepatopancreas. (a) Positive hybridization signal to probe EC592 is observed within HPV intranuclear inclusion bodies (arrowheads). An HPV intranuclear inclusion body (arrow) released from a cytolytic cell and showing a strong hybridization signal can be observed within the lumen of the hepatopancreatic tubule. (b) Positive hybridization signal (arrows) on the microvillous border of otherwise normal tubule epithelial cells. Fixation and staining: $2 \%$ glutaraldehyde without osmication. Probe hybridization plus toluidine blue stain. Scale bar $=10 \mu \mathrm{m}$ 
the non-specific deposition of silver occurred during the enhancing step. Control plastic sections also showed this phenomenon although silver deposition was much less evident than in paraffin sections.

\section{In situ hybridization with electron microscopy}

The results of the in situ hybridization observed by electron microscopy agreed with those obtained by light microscopy on semi-thin sections. Signal intensity was similar for samples preserved with any of the 3 fixatives tested. However, fixation in $4 \%$ paraformaldehyde $/ 0.25 \%$ glutaraldehyde was the less effective as it failed to provide suitable ultrastructure preservation. Osmication, on the other hand, preserved cellular morphology very well but markedly reduced probe signal. In general, background signal due to nonspecific deposition of silver was very low and could be differentiated from specific hybridization signal by the much smaller size of the deposits (see Fig. 7e).
The cellular structure displaying the strongest reaction to the probe EC592 was the intranuclear HPV inclusion. Nuclei exhibiting early to advanced viral inclusions showed gold granules almost exclusively in the viral stroma, with only a few gold particles scattered in the karyoplasm and nucleolus but not the marginated chromatin (Fig. 2a,b,c). Electron-lucent areas within the viral inclusion, known as intranuclear bodies (Kawase et al. 1990), also showed low hybridization signal (Fig. 2b).

A group of viral inclusions displaying a strong probe signal was found free within the lumen of a hepatopancreatic tubule in close proximity to the brush border of a tubule epithelial cell. None of the inclusions appeared to be bounded by a nuclear membrane. There was some evidence of their starting to dissociate or desegregate and they were surrounded by what appeared to be degenerated cell organelles (Fig. 3). There was scattered probe signal in the vicinity of these inclusions as well as in the microvilli of the tubule epithelial cell closest to them (Fig. 3).
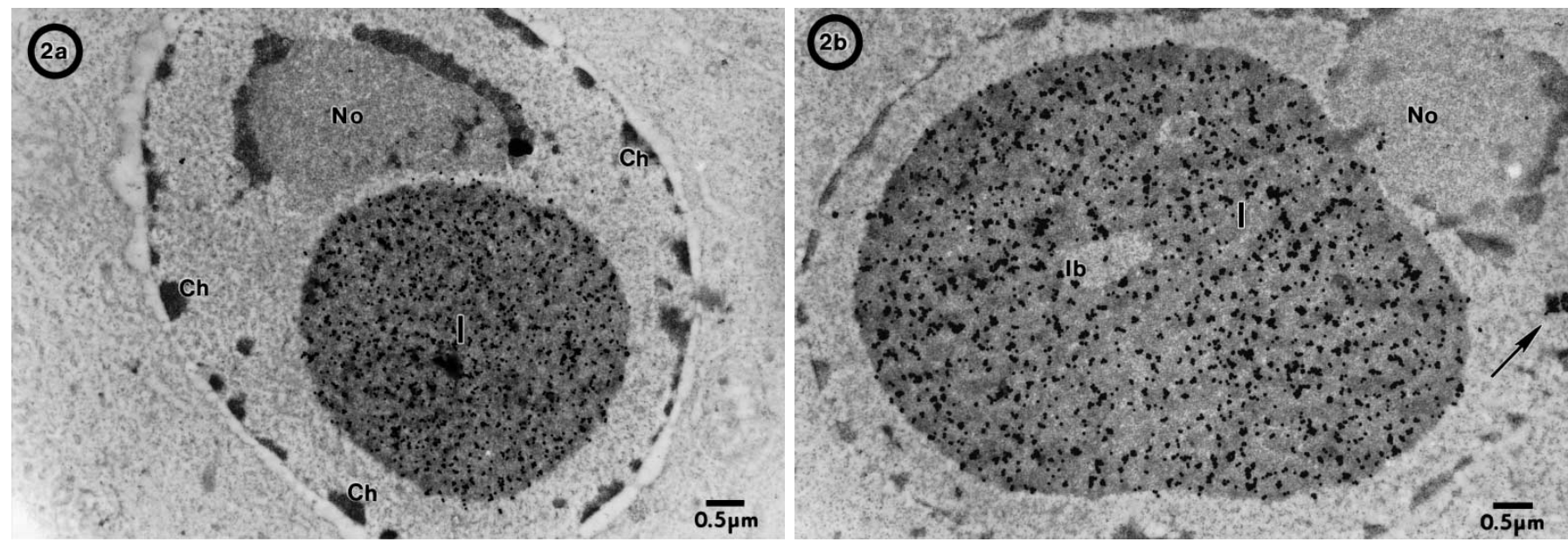

Fig. 2. Electron microscopy of ultra-thin sections of Unicrylembedded hepatopancreas. (a) Early developing intranuclear HPV inclusion body (I). Strong labeling by the probe EC592 can be observed within the virogenic stroma while the nucleolus (No) and marginated chromatin (Ch) appear completely devoid of signal. (b) Intranuclear HPV inclusion body (I), in a more advanced stage of development displays intense hybridization signal mostly within the virogenic stroma. Electron-lucent areas within the virogenic stroma, known as intranuclear bodies (Ib), show very low labeling intensity. A discrete cluster of gold granules can be observed free within the karyoplasm (arrow). The nucleolus (No) appears almost devoid of signal. (c) Advanced HPV intranuclear inclusion showing a positive reaction to the probe. Hybridization signal is limited to the virogenic stroma (I). The nucleolus (No) and marginated chromatin (Ch) are completely devoid of signal. Fixation and staining: All the specimens fixed in $2 \%$ glutaraldehyde, except (b), which was fixed in $6 \%$ glutaraldehyde. No osmication and lead citrate and uranyl acetate staining

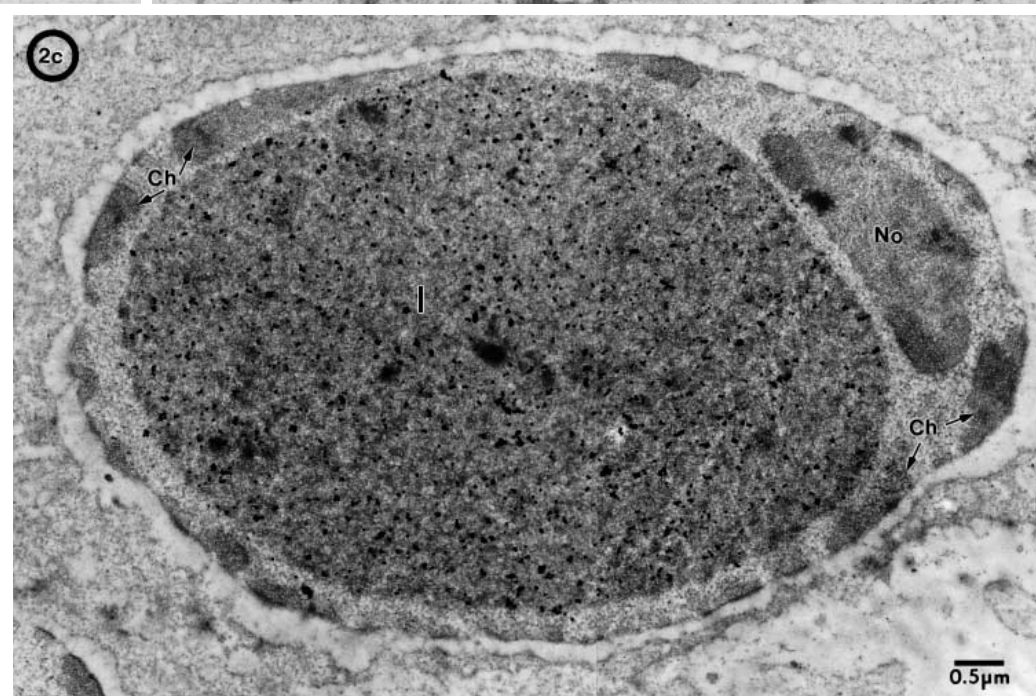




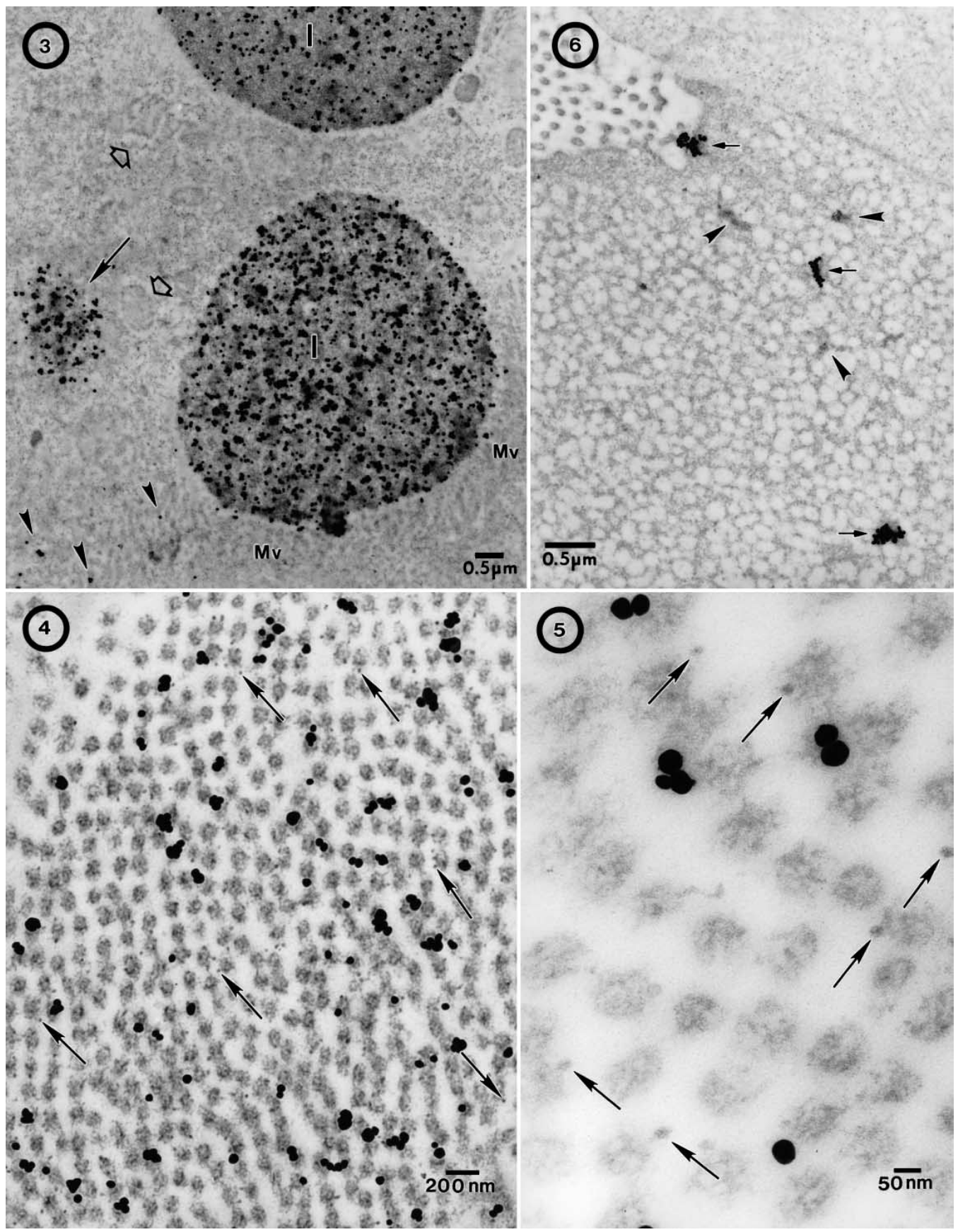

Figs. 3 to 6. Fig. 3. HPV intranuclear inclusion (I) bodies dislodged by cytolysis and free within the lumen of a hepatopancreatic tubule. Note the absence of a nuclear membrane surrounding the inclusion bodies. Intense hybridization signal is evident within both inclusions as well as in the small fragment on the left of the figure which may be an inclusion body in a more advanced stage of desegregation (solid arrow). One of the inclusions is in direct contact with the microvillous border (Mv) of a tubule epithelial cell, where scattered gold granules can also be observed (arrowheads). This group of inclusions is surrounded by what seems degenerated cell organelles (open arrows). Fixation and staining: $2 \%$ glutaraldehyde without osmication; lead citrate and uranyl acetate staining. Fig. 4. Cross section through the brush border of a tubule epithelial cell showing moderate to intense hybridization signal among the microvilli. The arrows mark some examples of small electron-dense $\sim 20 \mathrm{~nm}$ particles that are highly suggestive of virions attached to the microvilli. Fixation and staining: $2 \%$ glutaraldehyde without osmication; lead citrate and uranyl acetate staining. Fig. 5. High magnification of the hybridization signal observed among the microvilli of tubule epithelial cells. Note the presence of $\overline{\sim 20 \mathrm{~nm}}$ electrondense particles interspersed among the microvilli (some examples marked by arrows). Fixation and staining: $2 \%$ glutaraldehyde without osmication; lead citrate and uranyl acetate staining. Fig. 6. Discrete clusters of gold among the pinocytotic vesicles of the apical complex on a B-cell (arrows). Note the association of the signal to electron-dense amorphous aggregates, some of which are not labeled by the probe (arrowheads). Fixation and staining: $2 \%$ glutaraldehyde without osmication; lead citrate and uranyl acetate staining 
Probe signal was also detected in the brush border of other tubule epithelial cells, where there were no viral inclusions free in the lumen (Fig. 4). In this case, most of the signal occurred in the microvilli with few gold particles present within the cytoplasm. Small electrondense particles could be observed in close association with the microvilli where a positive reaction to the probe was evident (Figs. 4 \& 5).

Cytoplasmic probe signal was rather scarce but consistently associated with undefined amorphous electron-dense structures that did not seem to be limited by a membrane. In some instances, such amorphous structures were seen not inside pinocytotic vesicles but in between them (Fig. 6).

Similar structures showing a positive reaction to the probe were observed not only in the most apical region of the cell cytoplasm but also in close proximity to apparently normal nuclei (Fig. 7). Amorphous electron-dense structures, devoid of probe signal, were also found surrounding the nuclei of these cells (Fig. 7a,b). Discrete gold clusters were also observed in association with electron-dense areas within some nuclei where no viral inclusions were present (Fig. 7d,e). In such cells no probe signal was evident on any other nuclear structures.

\section{DISCUSSION}

Although Unicryl ${ }^{\mathrm{TM}}$ is considered a hydrophilic resin, penetration of reagents into the embedded tissue is rather limited and as with other hydrophilic resins, it occurs mostly at the surface of the section. Hence, DNA probe hybridization is expected to occur only with nucleic acids exposed at the surface of the section. Limited penetration of reagents and limited exposure of HPV nucleic acids were probably among the reasons why in situ hybridization signal was less intense in semi-thin plastic sections compared to paraffin sections. The short duration (5 $\mathrm{min}$ ) and the lower temperature $\left(18^{\circ} \mathrm{C}\right)$ of the silver enhancing step for ultra-thin sections probably resulted in the deposition of smaller background silver grains than those attached to enhanced gold particles, making it easier to differentiate between the two (Fig. 7e).

Lack of differences in hybridization intensity with any of the 3 fixatives tested probably resulted because the genome of HPV is single-stranded DNA. Fixation with glutaraldehyde concentrations higher than $1 \%$ has been counter-indicated for specimens subjected to in situ hybridization for electron microscopy (Le Guellec 1998) because of interference with the localization of double-stranded DNA. However, hybridization with single-stranded DNA is possible, especially after proteolytic (enzymatic) digestion (Puvion \& Pu- vion 1991). Indeed, the Proteinase K step increased intensity of the in situ hybridization reaction, suggesting that excessive DNA to protein cross-links had been removed. The absence of a DNA denaturation step in our hybridization protocol also suggested that the observed hybridization signals arose from singlestranded DNA in mature virions. Conceptually, a DNA denaturation step in addition to proteolytic digestion would be required before hybridization to detect HPV replicative dsDNA.

As would be expected, the strongest hybridization signal observed was within HPV intranuclear inclusions, the site of accumulation of mature virions. These inclusions are also referred to as virogenic stromata. The nucleolus appeared almost devoid of signal, regardless of the stage of viral development. By contrast, it has been reported for 2 other parvoviruses (AAV2 and $\mathrm{H}-1$ ) that mature virions are redistributed from the nucleolus into the nucleoplasm (Kasamatsu \& Nakanishi 1998). Nor did we find any probe signal associated with the marginated chromatin. On the other hand, discrete gold clusters which were apparently free were found apparently free within the nucleoplasm surrounding the virogenic stroma. These findings suggested either that HPV maturation occurred in the nucleoplasm within discrete 'islands' and later accumulated in the main inclusion or that maturation occurred within the main inclusion itself, or both. In the case of densoviruses, viral assembly and maturation is known to occur within the virogenic stroma (Kawase et al. 1990). The occurrence of hybridization signals in some nuclei with chromatin margination but without intranuclear viral inclusions suggested the possibility of precursors to virogenic stromata (Fig. 7d,e). On the other hand, it is also possible that the plane of section may have missed the stromata. Confirmation of these hypotheses must await the development of capsid protein antibodies that could be used in conjunction with DNA probes (such as EC592) to determine the nuclear compartments involved in HPV maturation.

Another interesting finding was the presence of HPV viral inclusions free within the lumen of hepatopancreatic tubules. During the last stage of the replication cycle, the accumulation of mature parvovirus particles is reported to cause disruption of the nuclear membrane and release of virions into the cytoplasm (Kawase et al. 1990). These features were not seen in our samples, even though free viral inclusions were observed within the hepatopancreatic tubule lumens. Thus, it is possible that there is a different mechanism for the release of HPV viral particles.

Our results suggest that spread of HPV infection in the hepatopancreas may occur through the liberation of whole intranuclear inclusions into the hepatopancreatic tubule lumens. There, we speculate that they 


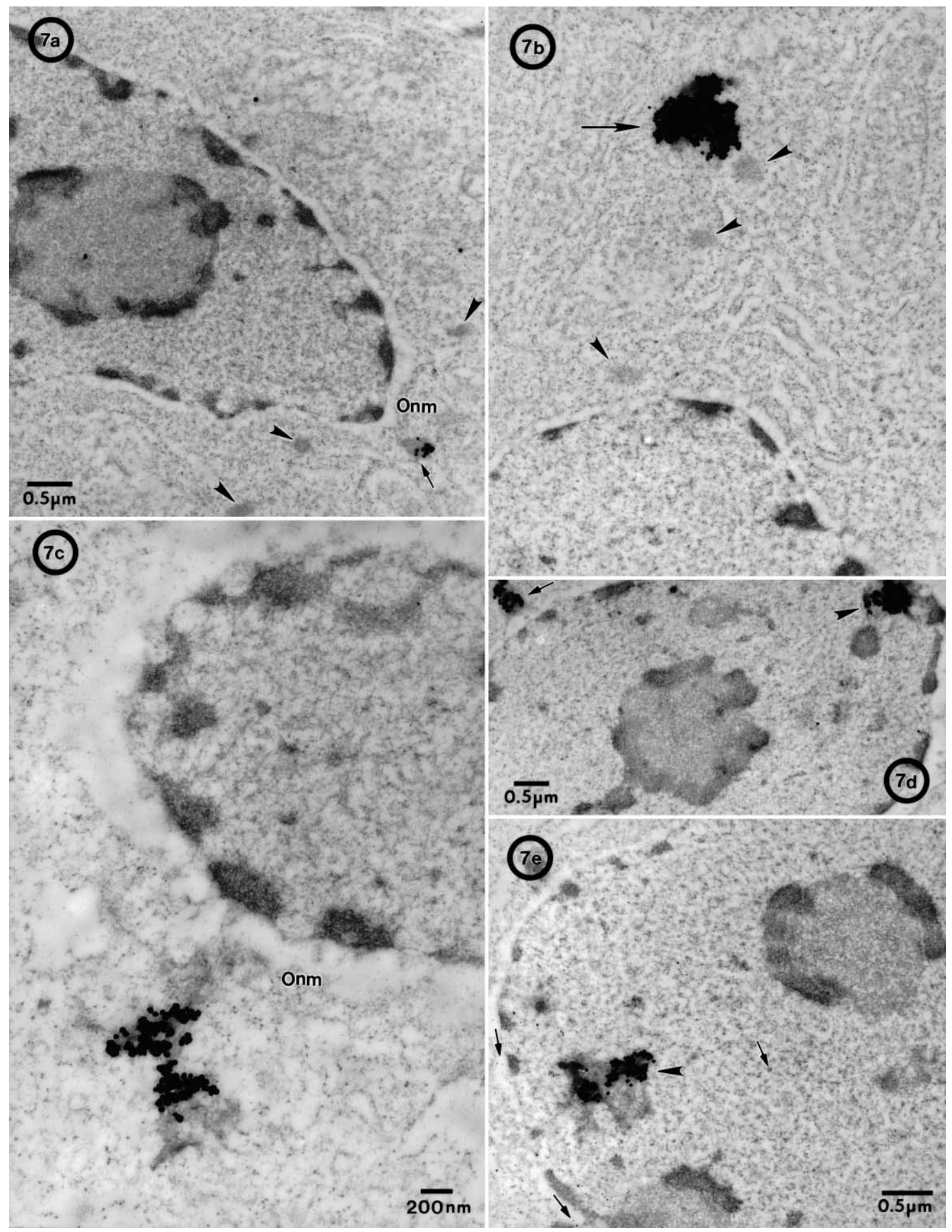

Fig. 7. (a) Discrete aggregate of gold particles (arrow) in the vicinity of the outer nuclear membrane (Onm). Note the association of the gold granules to this electron-dense body. Similar electron-dense structures can be seen in close proximity (arrowheads). The nucleus appears normal and devoid of signal. (b) Example of cytoplasmic hybridization signal (arrow) in close association with electron-dense bodies, some of which are not labeled by the probe (arrowheads). (c) High magnification of a positive cytoplasmic hybridization signal in close proximity to the outer nuclear membrane (Onm). (d, e) Examples of intranuclear hybridization signal where no intranuclear inclusion body is evident. Note the association of the signal to electron-dense structures (arrowheads), possibly precursors of the virogenic stroma. A discrete cluster of gold granules can be observed in the vicinity of the outer nuclear membrane in (d) (arrow). Examples of non-specific deposition of silver granules are marked by arrows in (e). Fixation and staining: $2 \%$ glutaraldehyde without osmication; lead citrate and uranyl acetate staining 
desegregate from the action of digestive enzymes and physical constriction of the tubules that are similar to peristaltic movements. Released HPV virions could then adsorb to and penetrate into new host cells. In this regard, a positive probe reaction was obtained with $\sim 20 \mathrm{~nm}$ objects (viral particles?) closely associated with the microvilli (Figs. 4 \& 5).

Regarding penetration of viral particles into the host cell, probe labeling was observed in association with electron-dense structures, possibly pinocytotic-like vesicles, in the vicinity of the brush border of cells that showed no evidence of HPV intranuclear inclusions. This was in agreement with the results reported by Mari et al. (1995). Apparently uninfected B-cells (Fig. 6) also showed discrete clusters of gold granules among numerous pinocytotic vesicles in the apical cytoplasm (apical complex). However, these probably would not result in productive infections since autonomous parvoviruses require the host cell to go through the S phase in order to replicate (Berns 1996) and since the E-cell type is the only hepatopancreatic cell type capable of mitotic division (Icely \& Nott 1992).

Characteristic HPV intranuclear inclusions displaying a positive reaction to the probe EC592 were observed within F-cells (not shown), which are also incapable of mitotic division. Since F-cells develop by differentiation from E-cells (Icely \& Nott 1992), these findings suggest that an E-cell can still differentiate into an F-cell after HPV infection. Since such differentiation must depend on a normally functioning nucleus, questions arise as to whether the virus replicates simultaneously or whether viral replication is slowed or suspended until cellular differentiation has been completed.

In conclusion, the present study has demonstrated the feasibility of detecting HPV nucleic acids with electron microscopy using a DIG-labeled HPV-specific gene probe and immunogold-silver enhancing techniques. In our attempt to document at least part of the replication cycle of HPV, evidence for the following processes was identified: adsorption, penetration, transport within the cytosol, penetration into the nucleus, replication, and release. Issues related to spatial localization of replicative intermediates may be addressed by slight modifications to the reported protocol. Other questions such as the distribution of structural proteins must await the development of appropriate probes.

Acknowledgements. This research was funded by the Gulf Coast Research Laboratory Consortium Marine Shrimp Farming Program, Cooperative State Research, Education, and Extension Service (CSREES), US Department of Agriculture under Grant No. 95-38808-1424, the National Sea Grant Program, US Department of Commerce under Grant No.
NA56RG0617. The Mexican National Council of Science and Technology (CONACYT) provided financial support through a fellowship awarded to C.R.P. to complete graduate studies at The University of Arizona. The shrimp stocks employed in this study were kindly provided by Mr Jie Huang (HPVinfected Penaeus chinensis from the Yellow Sea Fishery Research Institute, Qingdao, Shangdong, China) and by Dr James Brock of the Anuenue Fisheries Research Center, Honolulu, HI (HPV-infected Penaeus monodon from Madagascar). Geena Zhang and Peggy McCuskey, from the Imaging Facility Division of Biotechnology of The University of Arizona, are thanked for their technical support and for allowing us to use their UV polymerization chamber.

\section{LITERATURE CITED}

Beals TF (1992) Ultrastructure of in situ hybridization. Ultrastructural Path 16:87-93

Berns KI (1996) Parvoviridae: the viruses and their replication. In: Fields BN, Knipe DM, Howley PM et al. (eds) Fundamental virology, 3rd edn. Lippincott-Raven Publishers, Philadelphia, p 1017-1041

Binder M (1987) In situ hybridization at the electron microscope level. Scanning Microsc 1(1):331-338

Bonami JR, Mari J, Poulos BT, Lightner DV (1995) Characterization of hepatopancreatic parvo-like virus, a second unusual parvovirus pathogenic to penaeid shrimps. J Gen Virol 76:813-817

Escaig-Haye F, Grigoriev I, Sharova I, Rudneva V, Buckrinskaya A, Fournier JG (1992) Ultrastructural localization of HIV-1 RNA and core proteins. Simultaneous visualization using double immunogold labeling after in situ hybridization and immunocytochemistry. J Submicrosc Cytol Pathol 24:437-443

Flegel TW, Fegan DF, Kongsom S, Vuthikornudomkit S, Boonyaraptalin S, Chantanachookhin Ch, Vickers JE (1992) Occurrence, diagnosis and treatment of shrimp diseases in Thailand. Diseases of penaeid shrimp. In: Fulks W, Main KL (eds) Diseases of cultured penaeid shrimp in Asia and the United States. The Oceanic Institute, Honolulu, p 57-112

Flegel TW, Thamavit V, Pasharawipas T, Alday-Sanz V (1999) Statistical correlation between severity of hepatopancreatic parvovirus infection and stunting of farmed black tiger shrimp (Penaeus monodon). Aquaculture 174:197-206

Geuskens M, May E (1974) Ultrastructural localization of SV40 viral DNA in cells, during lytic infection, by in situ molecular hybridization. Exp Cell Res 87:175-185

Holthuis LB (1980) Shrimps and prawns of the New World. FAO Species Catalog, Vol 1. Food and Agriculture Organization of the United Nations, Rome

Icely JD, Nott JA (1992) Digestion and absorption: Digestive system and associated organs. In: Harrison FW, Humes AG (eds) Microscopic anatomy of invertebrates, Vol 10. Decapod Crustacea. Wiley-Liss Inc, New York, p 147-201

Jacob J, Tood K, Birnstiel ML, Bird A (1971) Molecular hybridization of $\left({ }^{3} \mathrm{H}\right)$ ribosomal RNA with DNA in ultrathin sections prepared for electron microscopy. Biochem Biophys Acta 228:761-766

Kasamatsu H, Nakanishi A (1998) How do animal DNA viruses get into the nucleus? Annu Rev Microbiol 52: $627-686$

Kawase S, Garzon S, Su DM, Tijssen P (1990) Insect parvovirus diseases. In: Tijssen $\mathrm{P}$ (ed) CRC handbook of parvoviruses, Vol II. CRC Press, Boca Raton, p 213-228 
Le Guellec D (1998) Ultrastructural in situ hybridization: a review of technical aspects. Biol Cell 90:297-306

Lightner DV (ed) (1996) A handbook of shrimp pathology and diagnostic procedures for diseases of cultured penaeid shrimp. Special publication of the World Aquaculture Society, Baton Rouge, LA

Lightner DV, Redman RM (1985) A parvo-like virus disease of penaeid shrimp. J Invertebr Path 45:47-53

Lightner DV, Redman RM (1991) Hosts, geographic range and diagnostic procedures for the penaeid virus diseases of concern to shrimp culturists in the Americas. In: De Loach P, Dougherty WJ, Davidson MA (eds) Frontiers in shrimp research. Elsevier Science Publishers, Amsterdam, p 173-196

Lightner DV, Bell TA, Redman RM, Mohney LL, Natividad JM, Rukyani A, Poernomo A (1992) A review of some major diseases of economic significance in penaeid prawns/shrimps of the Americas and Indopacific. In: Shariff IM, Subasinghe RP, Arthur JR (eds) Diseases in Asian aquaculture. Fish Health Section, Asian Fisheries Society, Manila, p 57-80

Lightner DV, Redman RM, Moore DW, Park MA (1993) Development and application of a simple and rapid diagnostic method to studies on hepatopancreatic parvovirus of penaeid shrimp. Aquaculture 116:15-23

Limuswan Ch (1999) Shrimp culture in Thailand toward year 2000. In: Tonguthai $K$, Chinabut S, Somsiri T, Chanratchakul P, Kanchanakan S (eds) The AAHRI Newsletter. Department of Fisheries, Kasertsart University, Bangkok, p 5-6

Lotz JM, Browdy CL, Carr WH, Frelier PF, Lightner DV (1995) USNSFP suggested procedures and guidelines for assuring the specific pathogen free status of shrimp broodstock and seed. In: Browdy CL, Hopkins JS (eds) Swimming through troubled water. Proceedings of the special session on shrimp farming, Aquaculture '95. World Aquaculture Society, Baton Rouge, p 66-75

Mari J, Lightner DV, Poulos BT, Bonami JR (1995) Partial cloning of the genome of an unusual shrimp parvovirus

Editorial responsibility: Timothy Flegel,

Bangkok, Thailand
(HPV): use of gene probes in disease diagnosis. Dis Aquat Org 22:129-134

Morey AL (1995) Non-isotopic in situ hybridization at the ultrastructural level. J Pathol 176:113-121

Morey AL, Ferguson DJP, Leslie KO, Taatjes DJ, Fleming KA (1993) Intracellular localization of parvovirus B19 nucleic acid at the ultrastructural level by in situ hybridization with digoxigenin-labelled probes. Histochem J 25(6): 421-429

Multhaupt HAB, Rafferty PA, Warhol MJ (1992) Ultrastructural localization of human papilloma virus by nonradioactive in situ hybridization on tissue of human cervical intraepithelial neoplasia. Lab Invest 67:512-518

Pantoja CR (1999) Hepatopancreatic parvovirus of penaeid shrimp (HPV): partial cloning and genome characterization, in situ hybridization at the ultrastructural level, geographic diversity and non-invasive detection. $\mathrm{PhD}$ dissertation, The University of Arizona, Tucson

Pantoja CR, Lightner DV (2000) A non-destructive method based on the polymerase chain reaction for detection of hepatopancreatic parvovirus of penaeid shrimp. Dis Aquat Org 39:177-182

Puvion-Dutilleul F, Puvion E (1989) Ultrastructural localization of viral DNA in thin sections of herpes simplex virus type 1 infected cells by in situ hybridization. Eur J Cell Biol 49:99-109

Puvion-Dutilleul F, Puvion E (1990) Replicating singlestranded adenovirus type 5 DNA molecules accumulate within well-delimited intranuclear areas of lytically infected HeLa cells. Eur J Cell Biol 52:379-388

Puvion-Dutilleul F, Puvion E (1991) Ultrastructural localization of defined sequences of viral RNA and DNA by in situ hybridization of biotinylated DNA probes on sections of herpes simplex virus type 1 infected cells. J Electron Microsc Tech 18:336-353

Spann KM, Adlard RD, Hudson DA, Pyecroft SB, Jones TC, Voigt MOC (1997) Hepatopancreatic parvo-like virus (HPV) of Penaeus japonicus cultured in Australia. Dis Aquat Org 32:239-241

Submitted: October 11, 1999; Accepted: November 9, 2000

Proofs received from author(s): January 30, 2001 